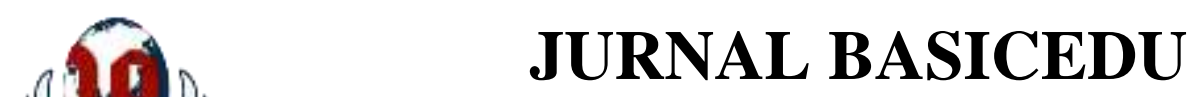

Volume 6 Nomor 1 Tahun 2022 Halaman 767 - 781

Research \& Learning in Elementary Education https://jbasic.org/index.php/basicedu

P AHLAWAN

\title{
Desain Pembelajaran IPS dan PKn Berbasis Teknologi Informasi di Tingkat Sekolah Dasar serta Penggunaan Media Teknologi Informasi dalam Proses Pembelajaran
}

\author{
Fitri Handayani $^{1 凶}$, Niki Yulianti ${ }^{2}$, Yeni Erita ${ }^{3}$ \\ Universitas Negeri Padang, Indonesia ${ }^{1,2,3}$ \\ E-mail: hfitri236@gmail.com¹ ${ }^{1}$, nikiyulianti89@gmail.com ${ }^{2}$, yenierita@ fip.unp.ac.id ${ }^{3}$
}

\begin{abstract}
Abstrak
Penulisan artikel ini memiliki tujuan mengumpulkan informasi untuk mendeskripsikan desain pembelajaran PKn dan IPS berbasis IT. Desain pembelajaran yaitu suatu proses yang dilakukan guru dalam mengembangkan, menciptakan dan merancang kegiatan belajar agar tercapainya tujuan yang diinginkan atau yang telah ditetapkan. Pada saat sekarang ini desain pembelajaran berbasis IT sangat digandrungi oleh berbagai kalangan dan juga keharusan dalam pendidikan. Di era teknologi yang canggih ini menuntut guru untuk kreatif dalam memanfaatkan teknologi dalam proses pembelajaran. Pengaruh IT dalam dunia pendidikan memberikan dampak yang sangat pesat sekali. Penelitian ini termasuk ke dalam jenis metode studi literatur. Data dikumpulkan dengan penelusuran dan menjelajahi jurnal melalui Google dan beberapa referensi seperti buku, dan lain sebagainya. Hasil analisis dari berbagai jurnal yang ditemukan menunjukkan bahwa desain pembelajaran berbasis IT yang dikatakan sebagai media pembelajaran berbasis IT memberikan pengaruh besar terhadap dunia pendidikan terkhusunya di sekolah dasar. Media tersebut dikembangkan diberbagai muatan pembelajaran termasuk IPS dan PKn.
\end{abstract}

Kata Kunci: Desain Pembelajaran, Media Pembelajaran IT, media pembelajaran PKn dan IPS berbasis IT

\begin{abstract}
The purpose of this article is to collect information to describe the design of IT-based Civics and Social Studies learning. Learning design is a process carried out by teachers in developing, creating, and designing learning activities to achieve the desired or predetermined goals. At this time, IT-based learning design is very loved by various groups and is also a necessity in education. This era of sophisticated technology requires teachers to be creative in utilizing technology in the learning process. The influence of IT in the world of education has a very rapid impact. This research belongs to the type of literature study method. Data is collected by searching and browsing journals via Google and some references such as books, etc. The results of the analysis from various journals found that the design of IT-based learning which is said to be an IT-based learning media has a major influence on the world of education, especially in elementary schools. The media was developed in various learning content including social studies and Civics.
\end{abstract}

Keyword: Learning Design, IT Learning Media, IT-based Civics and Social Studies Learning Media

Copyright (c) 2022 Fitri Handayani, Niki Yulianti, Yeni Erita

$\triangle$ Corresponding author :

Email : hfitri236@gmail.com

DOI : https://doi.org/10.31004/basicedu.v6i1.2034

ISSN 2580-3735 (Media Cetak)

ISSN 2580-1147 (Media Online)

Jurnal Basicedu Vol 6 No 1 Tahun 2022

p-ISSN 2580-3735 e-ISSN 2580-1147 
768 Desain Pembelajaran IPS dan PKn Berbasis Teknologi Informasi di Tingkat Sekolah Dasar serta Penggunaan Media Teknologi Informasi dalam Proses Pembelajaran - Fitri Handayani, Niki Yulianti, Yeni Erita

DOI: https://doi.org/10.31004/basicedu.v6i1.2034

\section{PENDAHULUAN}

Pendidikan sangat penting untuk menyiapkan peserta didik memiliki sikap karakter yang baik, pengetahuan, kecerdasan, dan memiliki keterampilan/keahlian. Dengan adanya pendidikan akan menjadi jembatan penghubung untuk mewujudkan pengetahuan kepada anak. Sebenarnya tujuan dari Pendidikan itu sendiri sudah dijelaskan dalam Pembukaan UUD 1945 dan digambarkan juga dalam Undang-Undang. Maka dari itu untuk mewujudkan tujuan yang tertulis tersebut direalisasikanlah dalam pembelajaran di lingkup sekolah. Dengan pembelajaran akan diberikan ilmu kepada anak untuk agar menjadi pribadi yang berfikir kritis. Apa yang diberikan kepada peserta didik tersebut tercantum dalam sebuah kurikulum. Dari dahulu hingga sekarang tatanan pengembangan pendidikan di Indonesia disusun dalam sebuah kurikulum. Kurikulum ini berisi berbagai hal yang akan diajarkan kepada peserta didik nantinya. Sebelumnya di Indonesia sudah terjadi berberapa pergantian kurikulum. Pada saat sekarang ini Indonesia memakai kurikulum 2013. Hal ini dapat dikatakan sebagai penyempurnaan dari kurikulum sebelumnya. Di mana hal ini lebih menekankan siswa pada pendidikan karakter, karena hal itu akan menjadi pondasi bagi siswa untuk menjadi anak yang mimiliki budi pekerti baik dan berakhlak mulia. Kurikulum 2013 mengedepankan bagaimana meningkatkan antara sikap, pengetahuan dan keterampilan. Ketiga aspek itu dapat dijadikan dasar bagi guru untuk melihat perkembangan berhasil atau tidaknya peserta didik dalam pembelajaran(Majid 2014). Zaman sebelumnya hingga saat sekarang ini pendidikan terus mengalami perkembangan, di mana perkembangan tersebut diiringi dengan teknologi yang canggih. Di era digital ini, semua hal berkaitan dengan pembelajaran dapat dipermudah dengan adanya teknologi yang dirancang oleh para ahli ataupun oleh guru. Dengan media ini diusahakan dapat mewujudkan dan meningkatkan kemampuan anak dari segi sikap, pengetahuan dan keterampilan.

Perkembangan zaman menuntut pembaharuan terhadap dunia pendidikan, hal ini harus diiringi dengan peningkatan mutu dalam proses pembelajaran salah satunya dengan melakukan pemanfaatkan teknologi informasi dan komunkasi dalam pmbelajaran agar mutu pembelajaran tercapai secara optimal. TIK awalnya sebagai alat penyampaian pesan penerangan. Kemudian beberapa ilmuwan berpendapat bahwa selain itu masih banyak keuunguulan dari TIK dalam berbagai bidang juga. Terutama dalam manfaatnya dalam peningkatan dilingkup pendidikan. Setelah berbagai penelitian dilakukan, terlihat manfaat yang luas dan besar dari media ini, di mana dapat digunakan sebagai alat penyampaian materi bahan pelajaran. Kemajuan Ilmu Pengetahuan dan Teknologi membawa pengaruh pesat dalam kehidupan manusia, mempengaruhi semua ruang lingkup kehidupan termasuk juga dalam dunia pendidikan yaitu pada pembelajaran IPS dan PKN. Kegiatan pembelajaran IPS yang baik yaitu suatu kegiatan pembelajaran yang dapat meningkatkan gairah, minat atau motivasi serta aktivitas siswa dalam belajar.

Peranan teknologi yang dapat dirasakan saat ini yaitu memperoleh informasi di bidang pendidikan yang nantinya akan bermuara untuk peningkatan proses belajar mengajar terutama dalam pembelajaran IPS dan PPKN. Hadirnya perkembangan teknologi berpengaruh terhadap alat bantu guru dalam membelajarkan materi kepada peserta didik. Di mana saat ini setiap guru dituntut untuk memiliki keterampilan dalam menggunakan bahkan menciptakan suatu media pembelajaran yang akan diterapkan dalam pembelajaran. Media pembelajaran dikatakan sebagai alat bantu guru dalam mengajar serta sarana pembawa pesan dari sumber belajar kepada peserta didik sebagai penerima pesan yang digunakan dalam pembelajaran berlangsung (Suryani 2016)

Dalam PBM dapat kita temui pada materi yang memiliki makna tersembunyi yang sulit dipahami oleh anak didik dan diluar pengalaman anak dilingkungan hidupnya akan sulit diajarkan dan akan sulit dipahami anak. Misalnya materi mengenai kejadian di masa lalu yang hanya tertulis secara kata-kata saja di dalam buku, hal ini kadang mengandung kata-kata yang abstrak. Seharusnya dibutuhkan hal yang konkret untuk dapat dijelaskan kepada peserta didik seperti penggunaan gambar, video bahkan animasi dapat di pertontonkan kepada anak. Tujuannya dapat menarik perhatian anak dalam belajar dengan penggunaan alat indra mereka. 
769 Desain Pembelajaran IPS dan PKn Berbasis Teknologi Informasi di Tingkat Sekolah Dasar serta Penggunaan Media Teknologi Informasi dalam Proses Pembelajaran - Fitri Handayani, Niki Yulianti, Yeni Erita

DOI: https://doi.org/10.31004/basicedu.v6i1.2034

Cara yang dapat dilakukan untuk mengkonkretkan materi yang bermakna tersembunyi ke arah yang memiliki makna nyata bagi anak. Visualisasi tersebut dapat digunakan guru dalam bentuk media pembelajaran berbasis IT, media ini dapat dikatakan sebagai alat yang terdiri dari hardware dan software serta segala aktivitas pengolahan data. Hal ini dapat menjadi pedoman guru dalam mengolah materi pelajaran yang menarik untuk anak didiknya.

Desain pembelajaran dapat kita ketahui maknanya dalam berbagai sudut pandang. Hal ini berkaitan dengan teori dan strategi dalam proses pengembangan pembelajaran serta bagaimana menerapkan atau melaksanakannya di dalam kelas. Selain itu juga dapat mengembangkan tingkat keterampilan guru dalam menyusun, mengolah, melaksanakan, melakukan penilaian terhadap anak didik dengan dirancangnya suatu produk tersebut. Tujuan dari rancangan ini pada dasarnya untuk berisi serangkaian langkah-langkah yang disusun serinci mungkin agar dapat meningkatkan mutu belajar anak di dalam proses pembelajaran. Masalah yang ditemukan dalam kenyataannya saat ini adalah masih kurangnya kemampuan yang dimiliki guru dalam merancang sebuah media pembelajaran berbasis IT. Selain itu juga disebabkan oleh alat pendukung yang tidak tersediadalam penggunaan media ini di dalam kelas. Dan tidak semua instansi memiliki ketersediaan alat $\mathrm{s}$ tersebut. Maka dari itu harus ada juga faktor pendukung dan penunjang dari berbagai pihak untuk mewujudkan serta merealisasikan hal ini. Disamping keterampilan dan pengetahuan yang dimiliki.

Dalam artikel ini, kami sebagai penulis akan membahas dan menjelaskan secara rinci tentang desain pembelajaran IPS dan PKn berbasis IT di sekolah dasar. Dijelaskan apa itu desain pembelajaran, media pembelajaran, media pembelajaran berbasis IT, desain pembelajaran IPS dan PKn di SD dan contoh media pembelajaran berbasis IT atau menggunakan aplikasi. Semua hal ini akan dijelaskan dalam hasil dan pembehasan. Supaya dengan adanya penjelasan ini dapat menjadi wawasan pagi pembaca untuk meningkatkan pengethuan, keterampilan, kreativitas, motivasi, hasil, dan lain sebagainya. Mendesain pembelajaran IPS-PKn berbasis IT dapat membantu guru ataupun peserta didik dalam proses pembelajaran agar pengetahuan dan materi pembelajaran dapat tersampaikan kepada siswa dengan baik. Selain itu pembelajaran yang dilalui peserta didik menjadi bermakna, mudah dimengerti, dan materinya lama tersimpan di memori anak bahkan apa yang telah ia diterima dapat diimplementasikan dalam kehidupannya.

\section{METODE}

Penelitian ini termasuk ke dalam penelitian kualitatif. karena data-data diinterpretasikan oleh penulis dengan memberikan gambaran dan penafsiran dari pemahaman yang temukan penulis, kenyataan dilapangan. Penelitian ini termasuk ke dalam penelitian kualitatif. Penelitian kualitatif dikatakan sebagai suatu penelitian yang dilakukan untuk memahami suatu peristiwa yang dialami oleh seseorang ataupun subjek yang menjadi kunci utama penelitian, di mana data yang didapatkan dari subjek akan dideskripsikan atau diinterpretasikan dalam bentuk kata-kata yang ditulis kemudian dituangkan ke dalam suatu paragraf bahkan bisa dari lisan seseorang serta dari sikap yang menjadi pusat pengamatan (Rejeki, Adnan, and Siregar 2020). Sedangkan pendapat menurut (Sugiyono 2017) berpendapat bahwa metode penelitian kualitatif termasuk ke dalam penelitian naturalistik karena penelitiannya dilakukan pada kondisi yang alami dan objek yang berkembang apa adanya.

Data penelitian ini didapatkan dan dikumpulkan melalui studi literatur, yang dilakukan dengan kajian kepustakaan dan dari penelusuran yang dilalukan di internet melalui google. Pendapat lain studi literatur merupakan suatu kegiatan yang berisi langkah-langkah dalam menemukan bahan bacaan yang dilakukan dengan cara menelusuri pustaka, membaca dan mencatat dari sumber teknologi, serta mengelolah bahan tersebut (Zed 2014). Data yang dikumpulkan dalam artikel ini adalah dengan melakukan penelusuran dan menjelajah berbagai jurnal di internet. Referensi ini juga didapat melalui buku, dan jurnal-jurnal yang telah publish. Sumber data yang akan dilaksanakan tidak langsung didapat dengan terjun ke lapangan. Maka dari itu, 
770 Desain Pembelajaran IPS dan PKn Berbasis Teknologi Informasi di Tingkat Sekolah Dasar serta Penggunaan Media Teknologi Informasi dalam Proses Pembelajaran - Fitri Handayani, Niki Yulianti, Yeni Erita

DOI: https://doi.org/10.31004/basicedu.v6i1.2034

studi literatur dikatakan sebagai metode dalam penelitian, untuk dapat mengumpulkan serta menganalisis sumber-sumber data untuk dikerjakan dalam bentuk laporan penelitian.Dalam studi literatur ini mencari referansi teori yang relevan.

\section{HASIL DAN PEMBAHASAN}

\section{Desain Pembelajaran}

Dalam proses pembelajaran sangat dibutuhkan sekali alat untuk menunjang pembelajaran agar lebih menarik sehingga siswa mudah dalam memahami materi pembelajaran. Dengan mendesain atau merancang pembelajaran dengan semenarik mungkin akan lebih disukai oleh peserta didik, dimana pada saat sekarang ini teknologi sudah semakin canggih yang dapat dimanfaatkan oleh berbagai kalangan. Desain itu sendiri dapat dikatakan sebagai kerangka rancangan maupun prosedur dalam mengembangkan suatu produk. Kita dapat merancang sebuah produk ataupun aplikasi dengan mengikuti langkah-langkah tertentu.(Basri, 2013)

Pembelajaran dapat dikatakan sebagai proses membelajaran apabila siswa berubah dari tidak tahu menjadi tahu. Tujuannya untuk membantu siswa mendapatkan output belajar yang baik melalui, mengikuti secara langsung dan menjadi bermakna bagi diri peserta didik itu sendiri (Helmiwati, 2012). Maksud lain dari pembelajaran ini yaitu suatu proses hubungan timbal balik antara semua unsur dan subjek yang ada di dalam kelas, yang akan menjadi pengendali dan kontrol utama di dalam kelas. Selama pembelajaran berlangsung, sela unsur dalam pembelajaran yaitu guru dan peserta didik menjadi pemeran utama untuk terwujudnya tujuan yang telah ditentukan. Pembelajaran tidak hanya kegiatan menstransfer/memberikan ilmu dari guru ke peserta didik, tapi proses yang berkesinambungan, berkelanjutan, merubah pola fikir peserta didik, menambah pengetahuan peserta didik dan menjadikan peserta didik anak yang berkarakter dan menjadi kebanggaan bangsa (Jihad, A., \& Haris 2013).

Kesimpulan Pembelajaran dikatakan sebagai serangkaian kegiatan yang tejadi antara pendidik dalam menjelaskan materi kepada peserta didik yang dikaitkan juga dengan lingkungan belajar tertentu sehingga akhirnya terjadi perubahan tingkah laku.

Kata dari desain pembelajaran dapat mengandung makna serangkaian aktivitas dalam merencanakan, mengolah, memproduksi bahkan menciptakan kegiatan belajar untuk mencapai suatu hal yang telah ditetapkan dengan mengaitkan kepada karakteristik peserta didik sebagai subjek yang dituju agar dapat ditingkatkannya keberhasilan belajar tersebut (Putrawangsa 2018). Desain pembelajaran memuat langkah-langkah yang sebelumnya dirancang oleh guru kemudian harus dilaksanakan dalam mengajarkan materi kepada anak didik sehingga menghasilkan output yang baik. Langkah kerja tersebut memiliki beberapa tahapan, mulai dari menganalisis kebutuhan, menetapkan perencanaan, melakukan pengembangan, mengimplementasikan, dan terakhir melakukan evaluasi terhadap apa yang telah dibuat.

Desain pembelajaran secara umum berisi prosedur pengembangan dan penyusunan program pendidikan yang bertujuan agar terjadi peningkatan dalam belajar. Desain pembelajaran disisi lain juga dikatakan sebagai proses yang dilakukan guru untuk memerbaiki dan meningkatkan output siswa dalam belajar dengan mengembangkan suatu bahan ajar dan menciptakan kegiatan belajar yang menarik sesuai dengan kebutuhan dan porsinya.

Di dalam Desain pembelajaran mencakup pengembangan bahan ajar, kegiatan menyusun strategi belajar, uji coba serta evaluasi terhadap seluruh kegiatan belajar. Guru harus memiliki keterampilan dalam desain pembelajaran, selain itu harus ada dalam diri guru pengalaman, keterampilan dan pengetahuan tentang pengaplikasian desain pembelajaran ini.

Beberapa penjelasan yang telah dipaparkan, dapat dipahami desain pembelajaran merupakan suatu aktivitas dalam merancang dan mengembangkan produk untuk menunjang proses pembelajaran agar menjadi 
771 Desain Pembelajaran IPS dan PKn Berbasis Teknologi Informasi di Tingkat Sekolah Dasar serta Penggunaan Media Teknologi Informasi dalam Proses Pembelajaran - Fitri Handayani, Niki Yulianti, Yeni Erita

DOI: https://doi.org/10.31004/basicedu.v6i1.2034

terarahkan sert dipahami oleh anak didik. Di mana dalam desain ini harus diikuti oleh beberapa langkah kerja akan terciptanya desain pembelajaran yang menarik.

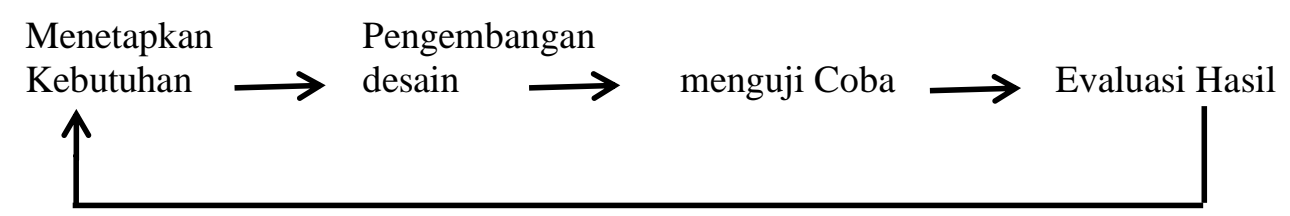

Gambar 1. Langkah-langkah Desain Pembelajaran Berbasis Teknologi Informasi

Prinsip penggunaan Pembelajaran Berbasis Teknologi Informasi

Menurut (Rahman 2018) Prinsip dalam penggunaan IT adalah sebagai berikut:

1. Penggunaanya yang maksimal. Karena jangkauannya yang mudah dan dapat juga mengefektifkan pembelajaran sehingga tidak memakan waktu dan biaya yang mahal menggunakannya.

2. Optimal. Dalam hal ini dilihat dari katerbarukan teknologi yang dapat mengoptimalkan hasil, nilai dan output pembelajaran.

3. Menarik. Artinya penggunaanya di dalam kelas dapat merangsang keinginan dan tingkat kepuasan siswa dalam mengikuti pembelajaran yang disampaikan guru. Sehingga pembelajaran tidak monoton dan tingkat produksi anak dapat bertambah.

4. Kemudian dapat Merangsang dayas berpikir kritis, logis dan kreatif peserta didik.

\section{Dampak Perkembangan Teknologi Informasi}

Pesatnya perkembangan it saat ini, sangat memberi warna dan memberikan tatanan baru dalam kehidupan kita dalam berbagai hal. Namun perlu kita sadari perkembangan teknologi informasi ini ibarat 2 sisi mata pisau yang memberikan dampak bagi kehidupan kita. Tentunya dampak ini terdiri dari dampak baik dan buruk yang bisa berpengaruh dalam kehidupan kita. Berikut adalah beberapa dampak dari kemajuan teknologi di bidang pendidikan yaitu : (Andriani 2015)

1. Dampak positif perkembangan TIK

a. Luasnya informasi yang dapat dijangkau dan ditemukan di internet. Contohnya saja kita berjualan, kita dapat mempromosikan produk kita melalui teknologi hingga sampai dilihat oleh orang diberbagai belahan bumi.s. Kemudian dapat kita dapat menyebarluaskan dan menerima informasi dari berbagai belahan dunia secara cepat.

b. Menemukan lebih cepat dalam dunia pendidikan. Perkembangan teknologi informasi ini membantu kita untuk menemukan informasi apapun yng berkaitan dengan dunia pendidikan. Apapun yang akan kita akses dapat kita temukan secara cepat tanpa harus menunggu lama. Makanya, kita bisa memanfaatkan teknologi untuk menemukan hal yang berkaitan dengan pendidikan. Disamping itu, kita sebagai tenaga pendidik dan pengajar juga dapat mengaplikasikan dan menerapkan konsep belajar aktif yang kreatif,efektif dan inovatif.

c. Dapat menghemat waktu dan biaya. Dengan adanya perkembangan teknologi Informassi dapat mempersingkat waktu serta menghemat biaya,. Misalnya kita akan mengirimkan uang kepada teman kita yang berjauhan tentunya kita dapat mentransfernya Via ATM atau melalui M banking hal ini tidak perlu kita pergi ke tempatnya cukup hanya dengan membuka HP saja. Tentunya manfaat nya dapat kita rasakan secara langsung tanpa harus pergi dan kapanpun yang kita inginkan waktunya.

d. Adanya Pustaka online, hal ini yang sebelumnya kita harus mengunjungi tempat perpustakaan terlebih dahulu unutuk mencari bahan materi pelajaran, karena adanya sistem digital dan online ini makanya dipermudah dengan adanya pustaka dalam bentuk digital. Hal ini dapat di akses oleh peserta didik dalam menemukan referensi terkiat materi pembelajaran. 
772 Desain Pembelajaran IPS dan PKn Berbasis Teknologi Informasi di Tingkat Sekolah Dasar serta Penggunaan Media Teknologi Informasi dalam Proses Pembelajaran - Fitri Handayani, Niki Yulianti, Yeni Erita

DOI: https://doi.org/10.31004/basicedu.v6i1.2034

e. Adanya pembahasan melalui internet seperti menggunakan zoom meeting, google meet, dan lain sebagainya.

f. adanya e-learning dalam melakukan PBM sehingga semakin memudahkan proses pendidikan tanpa harus bertatap muka langsung.

g. Hal yang berkaitan dengan dokumen pendidikan dapat di lancarkan dengan sisitem TIK. Tanpa harus memakan waktu yang lama.

2. Dampak Negatif TIK

a. Bisa terjadinya plagiarisme.

b. Adanya pengaruh buruk situs pornografi tidak dapat elakkan dan juga tidak dapat kita pungkiri, dengan bebasnya seseorang melakukan akses internet saat sekarang ini cendrung membawa pengaruh buruk bagi diri orang itu maupun lingkungannya. Hal ini akan memicu terjadinya sex bebas, sex di usia dini, dan dapat mendorong terjadinya pencabulan, pemerkosaan serta pergaulan bebas yang merusak moral. Banyak sekali terdapat situs atau web yang berbau pornografi yang memudahkan seseorang mengakses video yang tidak senonoh. Seharusnya anak-anak tidak perlu tau tentang hal ini. Makanya perlu pengawasan orang tua ketika anak memakai teknologi, supaya tidak terjerumus ke hal yang negatif. Hal ini menjadi tugas pemerintah dalam memfilter ketersediaan informasi dalam teknologi serta memberantas, menanggulangi serta mengatasi permasalahan pornografi ini.

c. Menjadikan orang malas. Ini merupakan dampak perkembangan teknologi informasi yang sudah merakyat di seluruh dunia. Apalagi banyak terjadi dalam dunia pendidikan. Kenyataan dilapangan banyak pelajar yang berkurang rasa keinginannya dalam memenuhi tugasnya sebagai pelajar untuk membuat pekerjaan rumah. Hal ini disebabkan oleh hadirnya internet, pelajar disuguhkan dengan berbagai konten yang meimikatnya untuk menghabiskan waktu menggunakan hp atau komputer. Mereka lebih ingin bermain dari pada belajar. Apalagi pada saat Pandemi ini, banyak ditemukan keadaan seperti itu. Makanya harus ada pengendalian dan kontrol dari orang tua.

d. Menjadikan manusia bersifat individualistis. Dampak negatif dari perkembngan teknologi infomasi adalah hilangnya rasa sosial dan kurangnya kemampuan berbaur dengan masyarakat. Kenapa ini bisa terjadi dikarenakan mereka sebagian suka dan merasa nyaman dengan kehidupan online dan hal ini berpengaruh buruk terhadap prilakunya. Jarang bertegur sapa, jarang berkomunikasi, jarang aktif di lingkungan sosial seperti kerja bakti, gotong royong menjadikan orng merasa tidak membutuhkan orang lain dan mengakibatkan terjadinya sifat individualistik dalam dirinya.

Selain pendapat di atas, pendapat lain Menurut (Japar 2018) Pengaruh positif teknologi di bidang pendidikan sebagai berikut:

1. Dalam proses pembelajaran sangat membantu sekali, karena dengan teknologi pembelajaran akan menjadi lebih cepat dan mudah.

2. Dengan teknologi dapat terjadinya virtual kelas, dimana sangat memudahkan para peserta didik untuk saling berkomunikasi antar sesama tanpa bertatap muka.

3. Memudahkan segala keperluan administrasi sekolah

Pengaruh negatif teknologi di bidang pendidikan:

1. Adanya situs yang tidak mendidik yang mempengaruhi akal pikiran dan merusak para pengguna. Misalnya situs pornografi, perjudian, dan lain sebagainya.

2. Sifat pemakai atau konsumtif semakin bertambah. Maksdunya semua hal menjadi instan dan dipermudah, seperti belanja pakaian /lifestyle semakin meningkat karena adanya teknologi. Seakan - akan hal ini menjadi kebutuhan primer manusia. 
773 Desain Pembelajaran IPS dan PKn Berbasis Teknologi Informasi di Tingkat Sekolah Dasar serta Penggunaan Media Teknologi Informasi dalam Proses Pembelajaran - Fitri Handayani, Niki Yulianti, Yeni Erita

DOI: https://doi.org/10.31004/basicedu.v6i1.2034

3. Terdapatnya Tindak kriminal, seperti tindakan ini dilakukan seseorang diinternet, bisa meretas situs-situs yang bersifat rahasia, bisa mencemarkan nama baik seseorang, bisa mencuri data pribadi kita dan bentuk kejahatan lainnya

Sesuai dengan penjelasan di atas, dapat simpulkan teknologi informasi memiliki dampak atau pengaruh positif dan negatif. Dampak positifnya mudah di akses, adanya virtual kelas, keperluan administrasi sekolah lebih mudah, adanya perpustakaan online, bisa diskusi online, dan adanya inovasi pembelajaran e-learning. Sedangkan dampak negatifnya adalah timbulnya rasa malas dalam diri seseorang karena sibuk dengan penggunaan IT, adanya situs-situs yang merusak seperti situs pornografi, perjudian, dan lain sebagainya.

\section{Media Pembelajaran Berbasis IT}

Kata "medium" adalah kata awal dari media yang muncul dari bahasa Latin, yang memiliki makna sebagai perantara penyampain pesan antara sumber dengan penerima (Tanwir, Rahman F, and Rahman F 2018). Media dapat kita pahami sebagai alat yang dapat digunakan sebagai penyalur informasi dari pemberi informasi kepada pendengar informasi (Ari Kusumawati and Prima Dewi PF 2019). Secara singkat yang sama-sama kita pahami bahwa media kalau kita lihat dari segi artinya sama dengan suatu perantara atau pengantar.

Perantara guru dalam menyampaikan dan menjelaskan materi pelajaran kepada anak didik dilakukan dengan bantuan media pembelajaran. Dengan hal ini dapat dilakukan dengan cara yang berbeda sehingga motivasi anak untuk belajar semakin meningkat. Secara singkatnya media pembelajaran ini membuat anak paham akan materi, kemudian akan berpengaruh terhadap output yang diterima anak berpua hasil belajar anak. Selain itu, juga dapat memperlancar kerja otak anak, karena mereka berpikir setelah memperhatikan media yang digunakan guru dan daya ingat anak akan bertambah juga. Dengan bertambahnya daya ingat anak terhadap materi pelajaran, maka akan berdampak terhadap prestasi belajar anak untuk ke depannya (Wahyuningtyas and Sulasmono 2020).

Perkembangan teknologi mempengaruhi perkembangan dari media penyampain pesan ini. Karena media dapat dikatakan baik apabila dapat mencapai dan mencakup tujuan yang diinginkan. Pembelajaran berbasis IT adalahmenggunakan alat teknologi sebagai alat bantu penyampaian materi kepada anak didik di suatu kelas. Konteks belajar dalam hal ini, peran guru hanyas membimbing anak didiknya untuk belajar dengan sumber belajarnya.

Perkembangan teknologi membawa pengaruh besar terhadap perkembangan media pembelajaran disekolah. Terjalinnya pembelajaran yang mengahsilkan output positif sebaiknya didukung dengan faktor medai pembelajaran yang digunakan. Di dunia pendidikan, pemanfaatan media sangat dianjurkan bahkan diupayakan untuk ada ketersediaanya dimasing-masing sekolah. Sebagai pondasai awal dalam memperoleh ilmu pengetahuan, sekolah dasar menjadi pusat dalam perolehan tersebut. Di sisni peserta didik dapat mengetahui semua pengethuan dari penyampaian materi yang dipakai guru. Dengan kecanggihan teknologi, maka manfaatkanlah ketersediaan teknologi tersebut. Sebagai pendidik guru diupayakan bisa memanfaatkan teknologi sebagai alat bantu dalam menjalankan proses pembelajaran agar menjadi menarik dan anak pun dapat paham akan pembelajarannya. Media pembelajaran dapat dikatakan sebagai peralatan yang dirancang secara senagaja, tersusun dan terarah untuk menyajikan informasi berupa materi pelajaran sehingga terjalinnya interaksi yang baik di dalam kelas. Alat tersebut berupa benda cetak, audio, visual, audiovisual, multimedia yang mencakup hal yang luas, dan web. Hal ini dibuat harus sesuai dengan karakteristik serta kebutuhan serta tujuan yang telah ditetapkan.

Media ini berupa alat bantu yang dipakai guru dalam mengajarkan materi pelajaran kepada anak didik serta sebagai sarana penyampaian pesan yang baik dan nyata. Sebagai penyampai dan penghubung dalam menyalurkan materi, media ini dapat mewakili guru jika guru berhalangan hadir. Jika media itu dirancang dengan baik, maka akan bermanfaat dan berfungsi dengan baik pula (Anjelika et al. 2019). 
774 Desain Pembelajaran IPS dan PKn Berbasis Teknologi Informasi di Tingkat Sekolah Dasar serta Penggunaan Media Teknologi Informasi dalam Proses Pembelajaran - Fitri Handayani, Niki Yulianti, Yeni Erita

DOI: https://doi.org/10.31004/basicedu.v6i1.2034

Pendidikan diera revolusi industri 4.0 ini menuntut para pendidik diberbagai tingkat pendidikan unutu kreatif dalam mengembangkan media pembelajaran digital, harapan dari semua ini adalah untuk meningkatakn wawasan generasi bangsa agar dapat berfikiri kritis sesuai dengan perkembangan zaman. Segala sesuatu yang menggunakan bantuan komputer dan internet disebut dengan media berbasis IT Pada saat ini penggunaan komputer saat belajar adalah hal yang lumrah dilakukan guru, berbeda dengan zaman dahulu. Penggunaan komputer/Laptop dapat direalisasikan dengan penyampaian materi serta dibantu oleh LCD dalam pemakaian di ruang yang luas. Tujuan hal ini yaitu melatih guru dan membantu siswa agar paham mengenai materi dan media digital itu. Saat ini teknologi komputer/laptop dapat berupa multimedia yang memungkinkan melihat secara langsung seperti adanya tampilan berupa teks, grafik, video, animasi, audio, dan lain sebagainya. Pemanfaatan komputer/laptop dapat dicipatakannya suatu media animasi kekinian yang menarik minat siswa untuk belajar. Di sekolah dasar penggunaan media pembelajaran sudah mulai diwujudkan oleh guru-guru. Hal ini juga harus disesuaikan dengan alat yang ada di sekolah tersebut. Di sini guru dapat merancang pembelajaran semenarik mungkin kemudian guru tanyangkan media tersebut di dalam kelas dengan LCD. Sehingga pembelajaran akan berlangsung menyenangkan dan peserta didik termotivasi untuk belajar (Tarigan 2019).

Sesuai dengan penjelasan di atas, dapat disimpulkan dengan perkembangan teknologi saat ini, menyediakan media pembelajaran berbasis IT dapat dijadikan sebagai alat bantu dalam belajar, dapat menunjang aktivitas belajar sehingga menjadi terarah dan anak tidak bosan dalam belajar serta anak dapat ikut serta selama proses pembelajaran. Media pembelajaran berbasi IT ini dapat berupa visual, audio, dan audio visual. Apalagi saat sekarang ini dengan teknologi sudah sangat mahir digunakannya, maka dari itu dengan teknologi media pembelajaran dapat diciptakan dalam berbagai bentuk yang kreatif dan inovatif.

\section{Fungsi dan Manfaat IT Dalam Pembelajaran}

Pemerintah mengupayakan perbaharuan terhadap bagaimana perkembangan pendidikan pada saat sekarang ini dengan melihat pendidikan di kancah dunia. Bagaimana negara kita dapat memperbaiki sistem belajarnya ke arah yang baik sehingga dapat setara mengikuti pendidikan di negara maju. Di negara maju penggunaan IT dalam pembelajaran suatu hal yang telah lama dilakukan karena dipenuhi oleh ketersediaan alat. Sedangkan di negara kita hal ini juga berangsur di wujudkan ketersediaan dan pemakaiannya. Medai IT itu sendiri memiliki begitu banyak manfaat dalam kehhidupan anak di sekolah. berbagai lingkup merasakan manfaatnya. Pemberikan pengalaman langsung kepada anak didik merupakan salah satu manfaat yang dirasakan karena anak terlibat lagsung dalam proses belajarnya menggunakan media IT. Menurut (Nurchaili 2010) manfaat IT dalam pembelajaran sebagai berikut:

1. Kualitas pembelajaran di dalam kelas akan meningat dengan hadirnya media IT

2. Dapat sebagai bekal pengetahuan dan keterampilan bagi peserta didik untuk masa depannya kelak

3. Menjangkau akses yang luas bagi pendidikan

4. Membuat minat, motivasi dan keaktifan peserta didik dalam belajar

5. Sebagai alat bantu dalam membelajarkan bahan materi

6. Meningkatkan keahlian dan kreativitas guru dalam membelajarkan materi

I Ketut Gede Darma Putra (2009) memberikan pendapatnya mengenai media yang dapat digunakan pada pembelajaran berbasis IT, yaitu:

1. Internet

Dengan adanya internet dapat memberikan kontribusi nyata unutuk pemanfaatan medai pembelajaran di sekolah. semua informasi berhubungan dengan pendidikan tersedia Internet. karena hal ini adalah bukti nyata media yang sesungguhnya dalam pendidikan berbasis TI.

2. Intranet

Untuk cakupan yang lokal intranetlah yang dibutuhkan. Misalnya didalam kelas, atau ruang lainnya. 
775 Desain Pembelajaran IPS dan PKn Berbasis Teknologi Informasi di Tingkat Sekolah Dasar serta Penggunaan Media Teknologi Informasi dalam Proses Pembelajaran - Fitri Handayani, Niki Yulianti, Yeni Erita

DOI: https://doi.org/10.31004/basicedu.v6i1.2034

Model yang baik dapat terjadi dengan mudah dan lebih murah jika dijalankan dengan intranet.

3. Mobile Phone

Penggunaan Hp saat ini sedang membludak karena ketersediaan jaringan internet yang meluas dan kebutuhan pembelajaran juga menggunakan HP. Berbagai kalangan dapat menelusuri materi pembelajaran melaui handphone ini. Apalagi saat pandemi melanda, telepon seluler dijadikan sebagai alat penghubung dalam membelajarkan materi kepada peserta didik.

Media pembelajaran berbasis TIK menggunakan smartphone harus memiliki daya tarik tersendiri yaitu dari karakteristik serta memuat bahan materi didalamnya,seperti (1) KI \& KD, yang harus dicapai oleh siswa; (2) materi disajikan dalam bentuk video animasi; (3) kuis, sebagai soal latihan; serta (4) evaluasi. Hal ini dapat memudahkan siswa dalam mempelajari materi proses pembelajaran menjadi tidak membosankan (Meidyanti 2021).

4. CD-ROM/Flash Disk

Media ini digunakan ketika koneksi jaringan internet tidak tersedia atau tidak terjangkau. Media ini dapat dimanfaatkan unutuk menyimpan bahan pelajaran yang telah didownload kemudian dapat dibuka dan simpan kembali ke komputer atau laptop. Pemanfaatan media ini adalah yang paling sederhana dan mudah.

Sependapat dengan penjelas di atas ada media pembelajaran berbasis ICT yang dapat dimanfaatkan dalam pembelajaran, diantaranya: (Suryani, 2016)

1. Teknologi komputer

Penggunaan dari teknologi komputer ini bisa dipakai ketika dalam keadaan offline. Kita bisa menggunakannya jika tidak terhubung ke internet, di mana bahan pelajarannya sudah didownload atau di simpan dalam komputer.

2. Teknologi multimedia

Hal ini berkaiatan dengan pemanfaatan media yang didukung dengan media lain seperti adanya speaker, laptop, LCD proyektor yang dapat memproses video dengan hasil yang baik jika ditayangkan di dalam kelas.

3. Teknologi telekomunikasi

Bagian dari telekomunikasi yaitu telepon, e-mail, dan lain sebagainya

4. Teknologi jaringan komputer

Salah satu contohnya adanya LAN, internet, wifi, dan lain-lain. Selaian itu juga terdiri dari perangkat lunak pendukungnya atau aplikasi jaringan seperti WEB, e-mail, php, dan lain sebagainya.

Ada banyak macam model yang akan digunakan oleh setiap orang dalam mengembangkan media pembelajaran. Model tersbut dipakai dengan menyesuaikan kebutuhan dari yang akan di buat. Salah satunya adalah model ADDIE. Model ini berupa proses yang akan dilalui perancang untuk mencipatak suatu produk. Pada prakteknya terdapat 5 fase yang membentuk siklus model ini, diantaranya: Analisis, Desain, Pengembangan, Implementasi, dan Evaluasi. 
776 Desain Pembelajaran IPS dan PKn Berbasis Teknologi Informasi di Tingkat Sekolah Dasar serta Penggunaan Media Teknologi Informasi dalam Proses Pembelajaran - Fitri Handayani, Niki Yulianti, Yeni Erita

DOI: https://doi.org/10.31004/basicedu.v6i1.2034

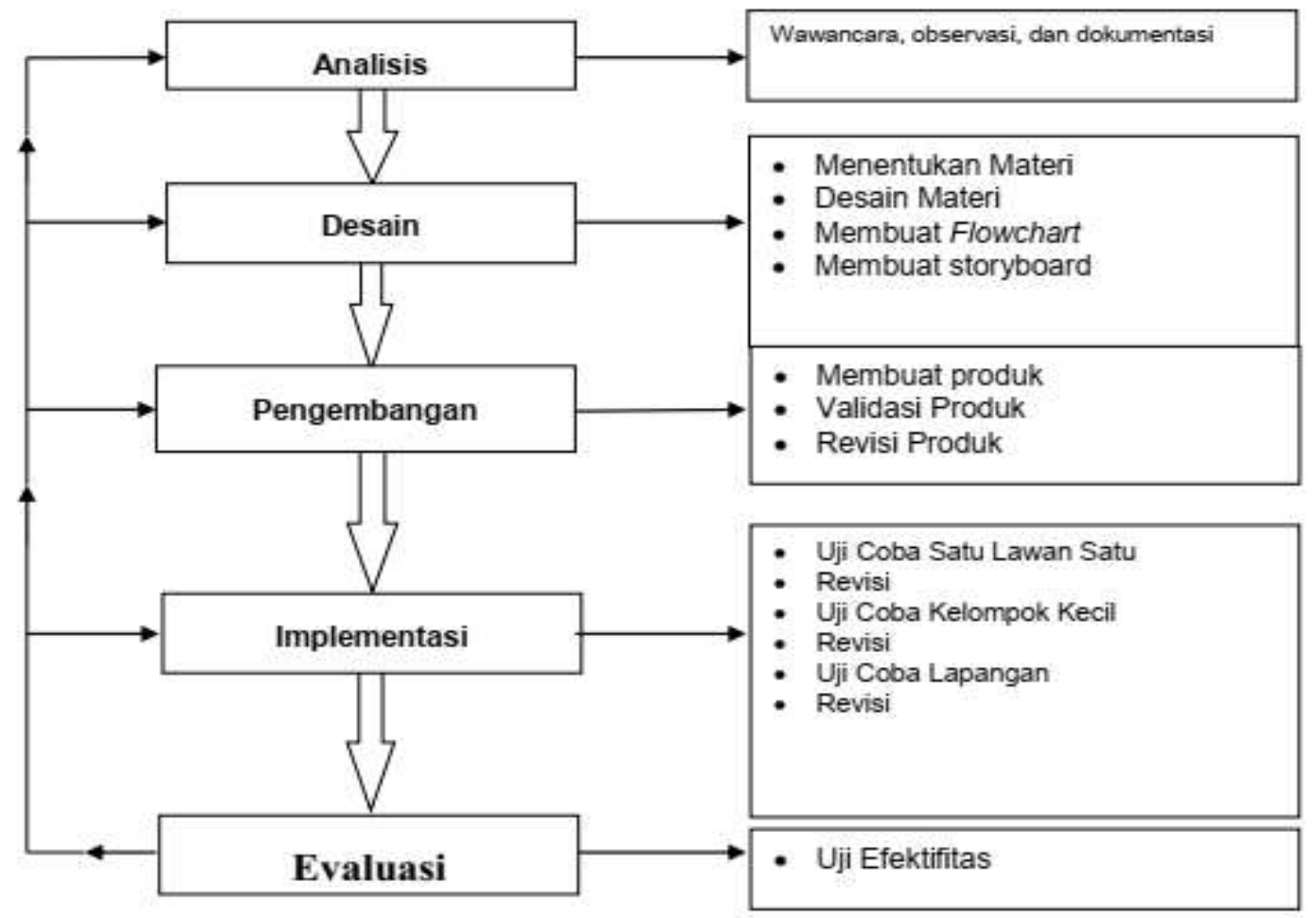

Gambar 2. Siklus ADDIE

Selanjutnya ada model ASSURE. Model ini berisi langkah-langkah sistematis dalam pengembangan media dengan memadukan penggunaan terknologi. Langkanya terdiri dari 6, yaitu: (Noviandi, S, and F 2020)

1. Menganlisis karakteristik anak didik

2. Kompetensi apa yang akan diajarkan harus disesuaikan

3. Menetapkan strategi, metode, media, dan bahan ajar yang menarik

4. Dimanfaatkannya bahan ajar dan media pembelajaran

5. Adanya keterlibatan peserta didik saat belajar

6. Proses evaluasi dan revisi dilakukan setelah semuanya dirancang.

\section{Mendesaian pembelajaran PKn dan IPS Berbasis IT}

IPS dikatakan sebagai mata pelajaran yang diterapkan kepada anak didik disemua tingkat sekolah. dalam hal ini IPS mengkaji mengai peristiwa, fakta, konsep dan generalisasi ilmu sosial. Selain itu juga memuat materi geografi, sejarah, sosiologi, antroplogi, psikologi sosial, politik, dan ekonomi. Dalam pembelajaran IPS, anak didik akan diajarkan bagaimana menjadi warga negara yang baik dan mampu berinteraksi dengan lingkungan sekitar. Fungsi ilmu pengetahuan sosial untuk bekal anak didik dimasa depannya, adanya keterampilan sosial dan intelektual sebagai warga yang bertanggung jawab (Sulistyowati, Prihatin \& Yasa, 2017).

Mempersiapkan peserta didik memiliki pengetahuan, sikap, nilai dan keahlian yang akan menjadi bekal baginya untuk memahami lingkungan sosial dan dapat diimplementasikan dalam memecahkan masalah kehidupan pribadi maupun masalah sosial. Selain itu juga menjadi pondasi bagi anak dalam mengambil suatu keputusan serta sikap anak berinteraksi dengan kehidupan bermasyarakat merupakan tujuan dari pendidikan IPS di skolah . menurut Adapun cakupan yang ada dalam mata pelajaran IPS adalah (a) adanya manusia, tempat, lingkungan, (b) waktu, keberlanjutan, dan perubahan (c) sistem sosial dan budaya, (d) perilaku ekonomi dan kesejahteraan (Intan Talitha and Cempaka Sari, 2016)

Pendidikan kewarganegaraan dapat dikatakan sebagai mata pelajaran wajib yang harus ditanamkan kepada anak dari sekolah dasar sampai ke perguruan tinggi. Di mana pendidikan ini dapat membangun karakter 
777 Desain Pembelajaran IPS dan PKn Berbasis Teknologi Informasi di Tingkat Sekolah Dasar serta Penggunaan Media Teknologi Informasi dalam Proses Pembelajaran - Fitri Handayani, Niki Yulianti, Yeni Erita

DOI: https://doi.org/10.31004/basicedu.v6i1.2034

serta moral yang baik dalam diri peserta didik (Anatasya and Dewi, 2021). Pendidikan Kewarganegaraan mengajarkan peserta didik bagaimana menjadi warga negara yang baik, warga negara yang cerdas, terampil, berkarakter dan mampu menjalankan hak dan kewajiban secara seimbang.

PKn bertujuan menjadi dasar dan tonggak untuk menjadikan anak yang berkarakter, cerdas dan baik serta mampu untukberpartisipasi dalam segala bidang. Memanfaatkan media pembelajaran dengan berbasis TIK dalam pembelajaran Pendidikan Kewarganegaraan adalah sebagai sarana yang digunakan untuk memudahkan guru dalam menyapaikan materi pelajaran melalui bantuan teknologi informasi dan komunikasi. Teknologi yag sedang berkembang pesaat saat ini seperti komputer/Laptop yang ditunjang dengan jaringan internet, pemakaian komputer/Laptop dan Infokus. Dengan memakai dan memanfaatkan media ini dalam pembelajaran PKn menjadi membuat suasanya belajar menjadi bervariasi, menyenangkan, meingkatkan motivasi anak serta konsentrasinya dalam belajar, dan meningkatkan daya pikir anak untuk memahami materi yang disajikan guru (Rahmadhani et al. 2021).

Berdasarkan hal itu, mendesain pembelajaran IPS dan PKn berbasis IT sangat diperlukan sekali dalam dunia pendidikan saat sekarang ini. Tidak hanya zaman saja yang berganti, tapi perkembangan IT pun sangat pesat perkembangannya yang dirasakan saat kondisi saat ini. Mendesain pembelajaran berbasis IT dilakukan sesuai dengan kebutuhan dan karakteristik peserta didik. Dalam mendesain pembelajaran kita harus melihat dari segala sisi, apakah media yang kita desain tersebut dapat bermanfaat dan apakah dapat berguna serta tersampaikan dengan baik kepada pesreta didik ataupun orang lain. Maka dari itu sebelum mendasain kita harus melihat cakupan analisis kebutuhan akan media, serta mengikuti langkah-langkah yang seharuasnya dilakukan dalam mendesain media pembelajaran.

\section{Contoh Media Pembelajaran PKn dan IPS Berbasis Teknologi}

1. Media Pembelajaran Pkn Berbasis Lectora Inspire

Media ini dapat dikatakan sebagai perangkat multimedia yang berguna dalam proses perngembangan media interaktif. Media ini akan disuguhkan dengan menarik, yang memuat berupa visual, audio dan audiovisual yang dapat menyampaikan bahan pelajaran dengan baik. Media pembelajaran ini pun dapat membimbing siswa untuk belajar mandiri dan otodidak sehingga semangat belajarnya meningkatkan. Selain bahan materi yang ditampilkan. Juga ada beberapa konten game yang dapat dipakai berkaitan dengan materi. Ketersediaanya alat bantu belajar ini membantu pendidik dalam mengajar di kelas, sehingga pembelajaran menjadi bermakna, efektif dan efisien. Pemanfaat media ini sudah ada dilakukan oleh para peneliti dengan membuktikan hasil yang bagus terhadap penggunaanya pada muatan pelajaran. (Syawaluddin, Makkasau, and Jamal, 2019). Pada pembelajaran IPS dan PKn media ini juga dapat dimanfaatkan tergantung pada materi yang akan diajarkan kepada peserta didik. Salah satu penelitian yang telah dilakukan oleh (Syawaluddin, Makkasau, and Jamal, 2019) mengenai "Pengembangan Media Pembelajaran Berbasis Aplikasi Lectora Inspire Pada Mata Pelajaran IPS Kelas V Di SDN 197 Sapolohe Kecamatan Bontobahari Kabupaten Bulukumba" penelitian ini mendapatkan hasil yang bagus di mana hasil pemanfaatan media ini dapat digunakan dengan layak dalam kegiatan belajar serta dapat menarik perhatian anak didik untuk belajar.

Dengan merancang media berupa gambar bahkan video dan juga kemudahannya dalam merancang evaluasi belajar yang interaktif adalah keunggulan yang dimiliki oleh aplikasi lectora. Lectora juga dapat digunakan untuk membuat website, konten presentasi yang disesuaikan dengan kebutuhan si perancang media (Andro and Kartika, 2015)

2. Media Pembelajaran berbasis Canva

Canva berupa aplikasi yang memuat berbagai fitur grafis secara online yang dapat dimanfaatkan oleh orang banyak dalam berbagai kepentingan. Dalam media pengantar ini memuat template yang beragam sesuai dengan bentuk yang akan dibuat oleh si perancang. Pemanfaatan media menghemat serta memudahkan dari segi waktu merancangnya serta membantu dalam menjelaskan materi (Rahma Elvira Tanjung, 2019). Media ini 
778 Desain Pembelajaran IPS dan PKn Berbasis Teknologi Informasi di Tingkat Sekolah Dasar serta Penggunaan Media Teknologi Informasi dalam Proses Pembelajaran - Fitri Handayani, Niki Yulianti, Yeni Erita

DOI: https://doi.org/10.31004/basicedu.v6i1.2034

dikembangkan sebagai alat bantu mengembangkan kreativitas dan keterampilan yang dimiliki, menciptakan pembelajaran yang hanya bersumber dari buku menjadi pembelajaran audiovisual sehingga komunikasi menjadi mudah dan menyenangkan.

Selain itu canva juga memiliki kelebihan, diantaranya:

a. Memuat dan menyuguhkan desain grafis yang menarik

b. Keterampilan yang sebelumnya dimiliki oleh guru akan bertambah dengan belajar menggunakan media ini (Garris Pelangi, 2020)

c. Pengaplikasiaan dan perancangannya dapat menghemat waktu secara praktis.

d. Selain menggunakan komputer atau laptop, media ini juga bisa di pakai melalui telepon seluler.

Kelebihan aplikasi Canva. Menurut (Garris Pelangi, 2020) adalah memudahkan seseorang dalam membuat desain yang diinginkan atau diperlukan dengan tersedianya berbagai template dan fitur yang menarik dan mudah dijangkau disemua kalangan karena bisa didapat melalui Android maupun komputer

Kelemahan aplikasi Canva yaitu bila ingin menggunakan Canva, setiap pemakai harus mempunyai paket data agar bisa tersambung dan dapat menggunakan Canva, kemudian template desainnya ada yang berbayar.

3. Media berbasis Powtoon

Powtoon adalah suatu aplikasi di internet yang dapat bermanfaat untuk menciptakan media dalam pembelajaran yang berbasis IT. Powtoon dapat diakses jika kita terhubung ke jaringan interent. Di dalam powtoon ini tersedia konten animasi baik kartun atau pun yang lain serta memiliki efek pergantian/operubahan yang dapat diatur dan disesuaikan dengan minat perancang (Ilahi and Desyandri, 2020).

Tersedianya media ini dapat mengatasi perbedaan gaya belajar dari setiap anak. Dengan menyaksikan video anak didik akan mendapatkan ransangan belajar dalam bentuk visual, audio dan audiovisual. Media ini akan mudah dipelajari oleh peserta didik karea kreasi yang disuguhkan yang dapat menarik perhatian dan konsentrasi anak untuk mengikuti pelajaran. Dengan hasil dari pengembangan media ini dapat diunngah di dunia maya yaitu Youtube, di mana nanti hasilnya dapat ditonton oleh orang banyak dan dapat dengan mudah diakses di mana pun orang berada.

Penggunaan media ini dapat dipakai dalam beberapa muatan pembelajaran, baik itu di muatan IPS dan PKn. Di semua muatan dapat dimanfaatkan media Powtoon, tergantung dari bahan yang akan diajarkan. Kalau untuk muatan PKn bagaimana menanamkan pendidikan karakter kepada peserta didik. Sedangakn IPS menanamkan konsep hubungan interaksi dengan lingkungan sekitar. Beberapa penelitian sudah memperlihatkan hasil mengenai penggunaan media Powtoon pada pembelajaran IPS amupun PKn. Hasilnya menunjukkan hal yang positif dimana dapat mengefektifkan pembelajaran. Menurut (Apriliani et al. 2021) hasil penelitian yang telah dilakukan mengenai "Pengembangan media pembelajaran PPKn SD berbasis Powtoon untuk mengembangkan karakter tanggung jawab" menunjukkan hasil yang optimal dalam Penggunaan media berbentuk video dengan bantuan powtoon ini memberikan pengaruh yang efektif bagi penanaman karakter dan sikap tanggung jawab kepada peserta didik. Maka dari itu, guru mengoptimalkan media ini untuk keberlangsungan pembelajaran PKn, bahkan di pelajaran lainnya.

a. Manfaat Media Pembelajaran Powtoon

1) Kejelasandalam menyajikan materi pelajaran

2) Megatasi keterbatasan materi yang memiliki objek yang besar dan cakupan materi yang luas.

3) Rekaman film atau vido dan lain sebagainya dapat digunakan untuk menampilkan materi yang bersifat luas, maupun materi berkaitan dengan kajian sejarah.

4) Diagram dan model dalam mendeskripsikan objek kajian yang kompleks

5) Cakupan materi yang luas visualkan ke dalam bentuk film, video, gambar, dan lainnya.

b. Kekurangan dan Kelebihan Media Pembelajaran Powtoon 
779 Desain Pembelajaran IPS dan PKn Berbasis Teknologi Informasi di Tingkat Sekolah Dasar serta Penggunaan Media Teknologi Informasi dalam Proses Pembelajaran - Fitri Handayani, Niki Yulianti, Yeni Erita

DOI: https://doi.org/10.31004/basicedu.v6i1.2034

Menurut (Muthmainnah. dkk 2021)yang termasuk ke dalam hal yang menjadi kelebihan dari mdia powtoon ini adalah dengan powtoon kita dapat berkreatifitas dalam menggunakannya sesuai dengan tema pembelajaran, bahasa yang ada di dalam powtoon dapat dikreasikan sehingga bisa dengan mudah dipahami anak SD, lamanya waktu yang dipakai tidak berdurasi lama tergantung guru yang membuatnya sehingga anak tidak merasa bosan, dalam mengaplikasikannya dapat dikatakn mudah tanpa keahlian khusus memakainya karena guru mengimplementasikannya dibantu oleh komputer/laptop, infokus, speaker dan alat pendukung lainnya.

Sedangkan kekurangannya yaitu kita dalam mengaksesnya harus terhubung ke jaringan internet, jika tidak terhubung tidak dapat digunakan. Kemudian memerlukan jaringan yang bagus dalam mengerjakannya, fitur di dalamnya tidak semuanya gratis karena ada yang berbayar. Selanjutnya dalam mengerjakannya dibutuhkan keterampilan dari guru yang akan membuat media menggunakan powtoon.

\section{KESIMPULAN}

Berdasarkan studi literatur yang telah penulis lakukan dengan berpedoman kepada hasil penelusuran terhadap jurnal-jurnal dan buku dapat disimpulkan bahwa untuk menunjang proses pembelajaran di ruang lingkup era digital ini dibutuhkan kreatifitas, pengetahuan dan keterampilan dalam merancang suatu media pembelajaran yang berbasis IT. Dengan dirancangnya media ini diberbagai muatan pembelajaran sesuai dengan materi pelajaran yang akan diajarkan. Dalam hal ini muatan pembelajarannya adala IPS dan PKn. Di mana dengan penggunaan media berbasis IT ini dapat meningkatkan motivasi, minat, kerativitas, aktivitas, bahkan hasil belajar anak didik. Karena anak terlibat langsung ikut aktif dan mengikuti langsung proses pembelajaran. Di sini guru dituntut di era digital ini untuk memanfaatkan media yang inovatif supaya pembelajaran di kelas semakin meningkat. Media pembelajaran berbasis IT dapat berupa penggunaan komputer, android, CDROM/Flash Disk dan internet. Selain itu beberapa aplikasi yang dapat dipergunakan sebagai alat untuk mengembangkan media pembelajaran berbasis teknologi seperti Powtoon, Canva dan Lectora Inspire. Berdasarkan beberapa penelitian yang telah dilakukan oleh peneliti lainnya menunjukkan hasil bahwa penggunaan media berbasis IT menghasilkan hasil yang positif terhadap pembelajaran. Dengan artikel ini dibuat dapat menjadi bahan wawasan bagi guru untuk ke depannya dapat mendesain pembelajaran IPS-PKn berbasis IT.

\section{UCAPAN TERIMA KASIH}

Rasa terima kasih penulis sampaikan kepada pihak yang telah membantu penulis dalam menyelesaikan artikel ini. Sehingga artikel ini dapat terselesaikan dan terwujud dengan semestinya serta nantinya artikel ini dapat sebagai pedoman bagi pembaca.

\section{DAFTAR PUSTAKA}

Anatasya, Ervina, and Dinie Anggareni Dewi. 2021. "Mata Pelajaran Pendidikan Kewarganegaraan Sebagai Pendidikan Karakter Peserta Didik Sekolah Dasar." Jurnal Pendidikan Kewarganegaraan Undiksha 9(2): 291-304. https://ejournal.undiksha.ac.id/index.php/JJPP/article/view/34133.

Andriani, Tuti. 2015. "Sistem Pembelajaran Berbasis Teknologi Informasi dan Komunikasi Tuti." Sosial Budaya: Media Komunikasillmu - Ilmu Sosial dan Budaya 12(1): 1-24.

Andro, Oleh, and Meda Kartika. 2015. "Lectora Inspire Sebagai Media Kelas Pada Pelajaran Pendidikan Kewarganegaraan ( Pkn ) Kelas Ii Sd." Tajdidukasi V(1): 1-11.

Anjelika, Gabriela et al. 2019. "Pengembangan Media Pembelajaran Pkn Berbasis It." 3: 912-14.

Apriliani, Medhitya Alda et al. 2021. "Pengembangan Media Pembelajaran PPKn SD Berbasis Powtoon Untuk 
780 Desain Pembelajaran IPS dan PKn Berbasis Teknologi Informasi di Tingkat Sekolah Dasar serta Penggunaan Media Teknologi Informasi dalam Proses Pembelajaran - Fitri Handayani, Niki Yulianti, Yeni Erita

DOI: https://doi.org/10.31004/basicedu.v6i1.2034

Mengembangkan Karakter Tanggung Jawab.” Jurnal Ilmiah Pendidikan Dasar 8(2): 129.

Ari Kusumawati, Niluh, and Kadek Aria Prima Dewi PF. 2019. "Pengembangan Media Pembelajaran Berbasis Teknologi Informasi Dalam Meningkatkan Mutu Pembelajaran Pendidikan Agama Hindu Abad 21.” Adi Widya: Jurnal Pendidikan Dasar 4(2): 168.

Basri. 2013. "Signifikansi Desain Pembelajaran Dalam Menunjang Kesuksesan Mengajar.” Nizham.

Garris Pelangi. 2020. "Pemanfaatan Aplikasi Canva Sebagai Media Pembelajaran Bahasa Dan Sastra Indonesia." Jurnal Sasindo Unpam, Vol 8, No 2, Desember 2020 Pemanfaatan 8(2): 79-96.

Helmiwati. 2012. Model Pembelajaran. Yogyakarta: Aswaja Pressindo.

Ilahi, Lisa Rahma, and Desyandri. 2020. "Pengembangan Media Pembelajaran Tematik Terpadu Berbasis Powtoon Di Kelas III Sekolah Dasar." Journal of Basic Education Studies 3(2): 1058-77.

Intan Talitha, Rahma, and Tiara Cempaka Sari. 2016. "Penerapan Metode Role Playing Untuk Meningkatkan Pemahaman Konsep Menghargai Keragaman Suku Bangsa Dan Budaya Di Indonesia Pada Pembelajaran Ips Kelas V Sdn Cijati.” Didaktik: Jurnal Ilmiah PGSD STKIP Subang 1(2): 231-41.

Japar, Muhammad. 2018. Teknologi Dan Informasi Pendidikan. Jakarta: Laboratorium Sosial Politik Press.

Jihad, A., \& Haris, A. 2013. Evaluasi Pembelajaran. Yogyakarta: Multi Pressindo.

Majid, Abdul. 2014. Pembelajaran Tematik Terpadu. Bandung: PT Remaja Rosdakarya.

Meidyanti, W E. 2021. "Pengembangan Media Pembelajaran Berbasis Teknologi Informasi Dan Komunikasi Pada Materi Pokok Jurnal Khusus Untuk Kelas XI Akuntansi SMK Negeri 1 Jember.” Jurnal Pendidikan Ekonomi 15(1): 123-29. https://jurnal.unej.ac.id/index.php/JPE/article/view/20273.

Muthmainnah. dkk. 2021. "Meningkatkan Hasil Pembelajaran Pendidikan Kewarganegaraan Menggunakan MediaPowtoon Selama Pembelajaran Jarak Jauhdi Sekolah Dasar.” Jurnal Basicedu 5(6): 5159-68.

Noviandi, Hendra, Neviyarni S, and Farida F. 2020. "Pengembangan Desain Pembelajaran Model Assure Menggunakan VAK Di Sekolah Dasar.” Jurnal Basicedu 4(4): 977-84.

Nurchaili. 2010. "Pengaruh Media Pembelajaran Berbasis Teknologi Informasi Dalam Proses Pembelajaran Kimia Terhadap Peningkatan Hasil Belajar Siswa.” Jurnal Pendidikan dan Kebudayaan 16(6): 648.

Putrawangsa, Susilahudin. 2018. Desain Pembelajaran: Design Research Sebagai Pendekatan Desain Pembelajaran. Mataram: CV. Reka Karya Amerta.

Rahma Elvira Tanjung, Delsina Faiza. 2019. "Canva Sebagai Media Pembelajaran pada Mata Pelajaran Dasar Listrik dan Elektronika Rahma Elvira Tanjung 1), Delsina Faiza 2) 1.” Jurnal Vokasional Teknik Elektronika dan Informatika 7(2): 79-85.

Rahmadhani, Defany Dwi, Indah Cahaya Putri, Dinie Anggraeni, and Yayang Furi Furnamasari. 2021. "Teknologi Informasi Dan Komunikasi Sebagai Salah Satu Pemanfaatan Pembelajaran Pendidikan Kewarganegaraan Di Sekolah Dasar.” Edukatif: Jurnal Ilmu Pendidikan 3(6): 4904-12.

Rahman, Ali. 2018. "Desain Model Dan Materi Pembelajaran Berbasis Teknologi Informasi." AL-ISHLAH: Jurnal Pendidikan Islam 16(2): 128-43.

Rejeki, Rejeki, M Fachri Adnan, and Pariang Sonang Siregar. 2020. "Pemanfaatan Media Pembelajaran Pada Pembelajaran Tematik Terpadu Di Sekolah Dasar." Jurnal Basicedu.

Sugiyono. 2017. Metode Penelitian Kuantitatif, Kualitatif Dan R\&D. Bandung: Alfabeta.

Sulistyowati, Prihatin \& Yasa, Arnelia Dwi. 2017. Pengembangan Pembelajaran IPS SD. Malang: Ediide Infografka.

Suryani, Nunuk. 2016. "Pengembangan Media Pembelajaran Sejarah Berbasis It." Sejarah dan Budaya : Jurnal Sejarah, Budaya, dan Pengajarannya 10(2): 186-96. 
781 Desain Pembelajaran IPS dan PKn Berbasis Teknologi Informasi di Tingkat Sekolah Dasar serta Penggunaan Media Teknologi Informasi dalam Proses Pembelajaran - Fitri Handayani, Niki Yulianti, Yeni Erita

DOI: https://doi.org/10.31004/basicedu.v6i1.2034

Syawaluddin, Ahmad, Andi Makkasau, and Ina Fitrayani Jamal. 2019. "Pengembangan Media Pembelajaran Berbasis Aplikasi Lectora Inspire Pada Mata Pelajaran IPS Kelas V Di SDN 197 Sapolohe Kecamatan Bontobahari Kabupaten Bulukumba.” JIKAP PGSD: Jurnal Ilmiah Ilmu Kependidikan.

Tanwir, Tanwir, Abd Rahman F, and Abd Rahman F. 2018. "Dampak Penggunaan Media Pembelajaran Berbasis Ict Terhadap Hasil Belajar Pai Peserta Didik Pada Smk Negeri 1 Kota Parepare." AL-ISHLAH: Jurnal Pendidikan Islam 16(1): 11-36.

Tarigan, Ester Emerita. 2019. "Pembelajaran Melalui Media Berbasis It Di Sekolah Dasar." 3: 987-90.

Wahyuningtyas, Rizki, and Bambang Suteng Sulasmono. 2020. "Pentingnya Media Dalam Pembelajaran Guna Meningkatkan Hasil Belajar Di Sekolah Dasar.” Edukatif: Jurnal Ilmu Pendidikan 2(1): 23-27.

Zed, Mestika. 2014. Metode Penelitian Kepustakaan. Jakarta: Yayasan Pustaka Obor Indonesia. 